\title{
Removal Of Crystal Violet Dye From Aqueous Solution with Pistachio Shell Powder: Optimization Of Process By Taguchi Method
}

\author{
Abdulaziz Kaya ${ }^{1 *}$ \\ ${ }^{1}$ Department of Metallurgical and Materials Engineering, Gaziantep University, Gaziantep, Turkey
}

Geliş / Received: 11/02/2021, Kabul / Accepted: 31/03/2021

\begin{abstract}
For environmental applications, the production of inexpensive but superior adsorbents is essential. The Taguchi method was applied as an experimental design in this paper to determine the optimum conditions for the removal of crystal violet dye using pistachio shell powder in batch experiments. The effects of $\mathrm{pH}(3-9)$, initial dye concentration (2-10 $\left.\mathrm{mg} \cdot \mathrm{L}^{-1}\right)$, contact time (30-360 mins) and adsorbent dose $\left(0.25-4 \mathrm{~g} \cdot \mathrm{L}^{-1}\right) \mathrm{were}$ studied using an L16 orthogonal array in order to achieve the maximum dye removal. For a "the-larger-thebetter" response, the percent dye removal was transformed into an accurate $\mathrm{S} / \mathrm{N}$ ratio. In the studied range for various parameters, the optimal condition was found to be $\mathrm{pH}=6$, initial dye concentration $=10 \mathrm{mg} \cdot \mathrm{L}^{-1}$, contact time $=360$ mins and adsorbent dose $=4 \mathrm{~g} \cdot \mathrm{L}^{-1}$. Under the optimum conditions, dye removal percentage was obtained to be $93.6 \pm 0.1 \%$. The analysis of variance results indicate that percentage contribution of control factor in descending order is adsorbent dose $(33.17 \%)>$ initial dye concentration $(27.43 \%)>\mathrm{pH}(22.89 \%)>$ contact time (16.52\%).
\end{abstract}

Keywords: Pistachio shell powder, Crystal Violet, Dye Removal, Taguchi Method.

\section{Kristal Viyole Boyanın Sulu Çözeltiden Antep Fıstığı Kabuğu Tozu ile Giderilmesi: İşlemin Taguchi Yöntemi İle Optimizasyonu}

\section{$\ddot{O} \mathbf{z}$}

Çevresel uygulamalar için, ucuz ancak üstün adsorbanların üretimi önemlidir. Taguchi yöntemi, kesik deneylerde fistık kabuğu tozu kullanılarak kristal viyole boyasının giderilmesi için optimum koşulları belirlemek için bu makalede deneysel bir tasarım olarak uygulanmıştır. PH (3-9), başlangıç boya konsantrasyonu (2-10 mg $\left.\cdot \mathrm{L}^{-1}\right)$, temas süresi (30-360 dakika) ve adsorban dozunun $\left(0.25-4 \mathrm{~g} \cdot \mathrm{L}^{-1}\right)$ etkileri bir L16 ortogonal dizi kullanılarak maksimum boya giderimini sağlamak için çalışılmıştır. Bir "daha büyük-daha iyi" yanıtı için, boya çıkarma yüzdesi, doğru bir $\mathrm{S} / \mathrm{N}$ oranına dönüştürülmüştür. Çeşitli parametreler için incelenen aralıkta optimum koşul; $\mathrm{pH}=6$, başlangıç boya konsantrasyonu $=10 \mathrm{mg} \cdot \mathrm{L}^{-1}$, temas süresi $=360$ dakika ve adsorban dozu $=4 \mathrm{~g} \cdot \mathrm{L}^{-1}$ olarak bulunmuştur. Optimum koşullar altında boya çıkarma yüzdesi $\%$ $93.6 \pm 0.1$ olarak elde edilmiştir. Varyans sonuçlarının analizi, kontrol faktörünün katkı yüzdelerinin azalan sırada adsorban dozu (\% 33.17) > başlangıç boya konsantrasyonu (\% 27.43) > pH (\% 22.89) > temas süresi (\% 16.52) olduğunu göstermektedir.

Anahtar Kelimeler: Fistık kabuğu tozu, Kristal Viyole, Taguçi Yöntemi.

\section{Introduction}

Environmental pollution has increased recently due to human population growth and rapid industrial development. Some of the most important environmental emission variables are organic based chemicals and effluents used in many industries (İnal and Erduran, 2015). Dyes constitute a significant class of organic contaminants, which are primarily used in the textile industry for coloring fabrics. Waste water containing color is produced in these industries as an inevitable output during the dyeing process. 
(Venkatesha et al., 2012). However, with the exception of bringing colors to the lives of people, much dyeing waste water is created annually and becomes an urgent and difficult source to handle. Many synthetic dyes are soluble in water, chemically stable and extremely biochemically toxic, which can cause major environmental issues and thus have a serious impact on marine life and human beings (Xing et al., 2019). Crystal violet $(\mathrm{CV})$, also known as gentian violet, is a common type of dye used in the textile, paper, and printing ink industries, as well as a biological stain, bacteriostatic agent in veterinary medicine, and skin disinfectant in humans (Sabna et al., 2016). Due to its toxic nature, it can cause cancer, extreme eye irritation, and is dangerous when inhaled, ingested, or comes into contact with the skin (Senthilkumaar et al., 2006). Therefore, eliminating dyes in general, and $\mathrm{CV}$ in particular, from water/wastewater is highly desirable.

At present, researchers have explored several approaches, including membrane filtration (Sachdeva and Kumar, 2009), oxidation (Malik and Saha, 2003), electrochemical process (Panizza et al., 2007), biological treatment (Punzi et al., 2015), and adsorption (Ertugay, 2018; Sarıkaya and Erden, 2020), for the treatment of colored waste water. Adsorption is considered as a promising method of moving the contaminants from the solution to the solid phase. The adsorption appears to be simple to design, available, easy to operate, does not yield hazardous materials and does not require high costs based on this consideration (Abd- Elhamid et al., 2020). In the adsorption processes, the chosen adsorbent should be environmentally friendly, economical and demonstrate high efficiency of removal. Activated carbon has been used successfully for the removal of dyes from waste water as an adsorbent. Even though the most commonly used adsorbent is activated carbon, it is expensive (Ates and Tezcan Un, 2013). Owing to the reduced cost of food waste and other wastes, various substitute materials have started to be used as adsorbents (Gezer and Ersoy, 2018). A significant number of of agricultural wastes for the removal of dyes, including rice husks (Ding et al., 2014), maize cobs (El-Geundi, 1991), peanut hull (Tanyildizi, 2011), almond shell (Ardejani et al., 2008), tea waste (Madrakian et al., 2012), wheat straw (Robinson et al., 2002), and saw dust (Garg et al., 2003), etc., have been investigated so far. It is still important to investigate modern, economical, easily available and highly effective adsorbents based on agricultural wastes.

Pistacia vera L. (Pistachio) plant belongs to the family of Anacardiaceae and is mostly grown in the Middle East, Mediterranean countries and the United States (Khan et al., 2015). In the confectionery, snack foods, ice cream and cake sectors, pistachio nuts are commonly used. Therefore, given the ratio of shell/pistachio $(\sim 45 \%)$, large amounts of pistachio shell occur (Açıkalın et al., 2012). These agricultural waste materials are produced in pistachio peeling mills and are available at no cost in bulk (Moussavi and Khosravi, 2011). Pistachio shells are often used for heating purposes and are not used in other industries (Şentürk and Alzein, 2020). Therefore, measuring the ability of pistachio shell waste to remove dyes from waste water is quite important.

There are several variables that can influence the efficiency of dye adsorption, including solution $\mathrm{pH}$, temperature, initial dye concentration, adsorbent dose, etc. Every adsorbent's optimum operating conditions for 
certain dye adsorption are different However, the large-scale implementation and understanding of the adsorption mechanism would greatly benefit from optimizing such conditions (Zhou et al., 2019). To assess the optimum conditions for dye removal, the system parameters have been investigated.

To achieve the best response under the given removal conditions, optimization techniques have been used, such as the response surface methodology based on central composite design (Pourebrahim et al., 2017) and the Taguchi technique (Chen et al., 2014). The Taguchi experimental design technique is a simple and efficient technique compared to the central composite design, which can be used more economically for product or process optimization (Berkane et al., 2020). The Taguchi method, which offers an effective way to design products that function consistently and optimally under a variety of circumstances, was used to formulate the experimental plan and to elaborate on the experimental results obtained. The Taguchi method makes it possible to identify which controllable factors minimize the change in outcomes and render the product insensitive to changes induced by uncontrollable factors. In this approach, parameters are set to minimize variance in response, modifying at the same time the effects of the process on target (Pander et al., 2016). In optimizing dye removal studies, such as guava seed carbon for acid orange 7 adsorption (ElizaldeGonzález and Hernández-Montoya, 2009), Pleurotus ostreatus for malachite green adsorption (Chen, Deng et al., 2014), and potato peel for direct blue 71 removal (Maleki et al., 2015), this approach has been used. However, there is no literature available on optimizing the removal of $\mathrm{CV}$ dye from aqueous solutions by pistachio shell powder using the Taguchi method design.

The main aim of the present study was to investigate the ability of pistachio shell powder under various experimental conditions to remove a cationic dye, CV dye, from liquid media. To optimize the dye removal system, Taguchi experiment design was employed to find the effect of various parameters including $\mathrm{pH}$, initial dye concentration, contact time, and adsorbent dose. Our results showed that adsorbent dose is the most important factor in the removal process of $\mathrm{CV}$ molecules from aqueous solution by pistachio shell powder.

\section{Material and Methods}

\subsection{Materials}

From a local pistachio processing factory, pistachio shells used in the batch experiments were obtained. First, the shells were washed several times with deionized water for the removal of dirt, dust and other impurities on their surface. The washed shells were then air-dried for a week, crushed, grounded using a hammer mill and sieved in the size range of 0-250 $\mu \mathrm{m}$. The resulting pistachio shell powder (PSP) was stored in a glass bottle and used for experiments as needed.

All chemicals were used as supplied without further purification. Sodium hydroxide $(\mathrm{NaOH})$ and hydrochloric acid $(\mathrm{HCl})$ were procured from Tekkim Kimya San. Ltd. Crystal violet (molecular formula: $\mathrm{C}_{25} \mathrm{H}_{30} \mathrm{~N}_{3} \mathrm{Cl}$, molecular mass $=407.98 \mathrm{~g} / \mathrm{mol}$, purity $>88.0 \%$; Figure 1) was purchased from Merck. Deionized (DI) water was used throughout this study. 


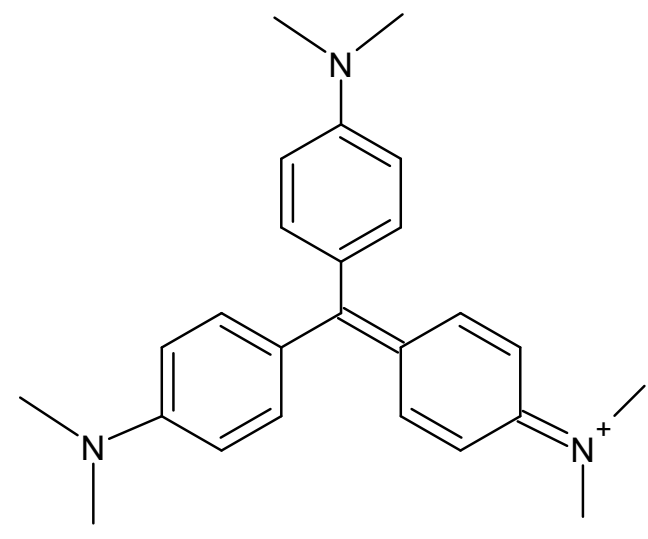

Figure 1. Chemical structure of crystal violet dye.

\subsection{Instrumentation}

The concentration of CV dye in solution was determined spectrophotometrically on a UVVisible Spectrophotometer (Shimadzu model: UV 1800). The $\mathrm{pH}$ of the dye solutions was measured using a Starter 3100 pH meter (Ohaus Corporation, USA).

\subsection{Batch Experiments}

A stock solution of $1 \mathrm{~g} \cdot \mathrm{L}^{-1}$ of the $\mathrm{CV}$ dye was prepared. All working solutions were obtained by diluting the stock solution with DI water. Batch adsorption experiments were carried out at $295 \mathrm{~K}$. The initial CV concentration used in the tests ranged between 2 and $10 \mathrm{mg} \cdot \mathrm{L}^{-1}$. PSP samples were weighted between 25 and $400 \mathrm{mg}$ to get the slurry concentrations in the range of $0.25-4.0$ $\mathrm{g}$ adsorbents per liter. Before adding the PSP into the dye solutions, the $\mathrm{pH}$ values of the dye solutions were adjusted by dropwise addition of $0.1 \mathrm{M} \mathrm{HCl}$ or $0.1 \mathrm{M} \mathrm{NaOH}$ aqueous solutions. A volume of $100 \mathrm{~mL}$ of CV solution with various amounts of PSP was placed in a $250 \mathrm{~mL}$ capped conical flask to start the experiments. The mixtures were stirred on a magnetic stirrer with a speed of $500 \mathrm{rpm}$ for predetermined time intervals (30 mins, 1
20 mins or 360 mins). At the end of the contact period, aliquots of samples were withdrawn and then centrifuged at $4500 \mathrm{rpm}$ for 10 mins to separate the PSP from the dye solution. The left out concentration in the supernatant dye solution were analyzed by using UV spectrophotometer at $\lambda_{\max }$ of 590 $\mathrm{nm}$. The effect of $\mathrm{pH}$ on $\mathrm{CV}$ dye's maximum absorbance wavelength was also monitored in this study. Figure 2 depicts the findings. The results show that $\mathrm{pH}$ had no effect on the maximum absorbance wavelength.

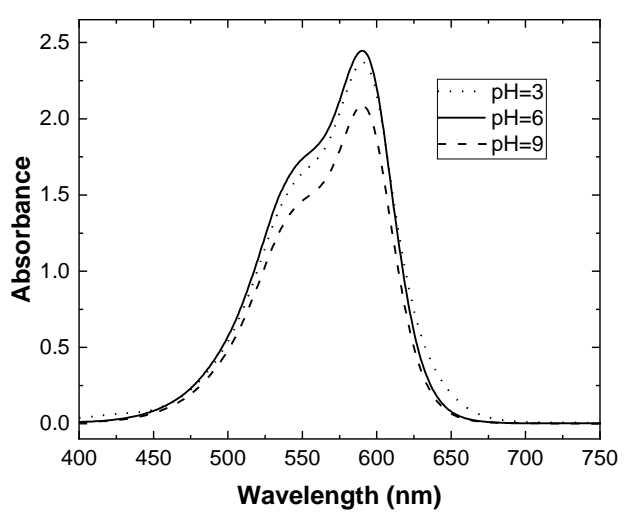

Figure 2. UV spectrum of CV dye solutions at different $\mathrm{pH}$ values (dye concentration = $10 \mathrm{mg} \cdot \mathrm{L}^{-1}$ )

All the experiments were performed in triplicate and all values are expressed as the mean \pm standard deviation. The blank experiments showed no detectable $\mathrm{CV}$ adsorbed on the walls of the flask. Dye removal percentage (\%) was calculated by the following equation:

dye removal $\%=\frac{\left(C_{i}-C_{t}\right)}{C_{i}} \times 100 \%$

where $\mathrm{C}_{0}\left(\mathrm{mg} \cdot \mathrm{L}^{-1}\right)$ and $\mathrm{C}_{\mathrm{t}}\left(\mathrm{mg} \cdot \mathrm{L}^{-1}\right)$ are the initial concentration of $\mathrm{CV}$ and concentration of CV at time $t$, respectively. 


\subsection{Design of Experiments by Taguchi method}

A simple and robust technique for optimizing the process parameters is the Taguchi design method. In this method, the key parameters that are expected to impact the process results are placed at different rows in a designed orthogonal array. In such an arrangement, it is possible to perform absolutely randomized trials (Kwak, 2005). For matrix tests, the objective function is the ratio of signal to noise $(\mathrm{S} / \mathrm{N})$. This is used to determine the performance attributes and the percent contribution of process parameters through the analysis of variance (ANOVA) (Fratila and Caizar, 2011). The $\mathrm{S} / \mathrm{N}$ ratio is the amount of variance present in the quality characteristic in which the mean value for the output characteristic is defined by the term $S$ and the unfavorable value for the output characteristic is represented by the value $\mathrm{N}$ (Do and Hsu, 2016). Depending on the desired output response, there are different types of $(\mathrm{S} / \mathrm{N})$ ratio, including the-nominalthe-better, the-smaller-the-better, and thelarger-the-better. In this paper, the larger-thebetter $\mathrm{S} / \mathrm{N}$ was used because the purpose is to achieve high dye removal percentage values. Therefore, the equation presented by Taguchi for $\mathrm{S} / \mathrm{N}$ calculation complying wih the largerthe-better criteria is:

$$
S / N=-10\left(\log \frac{1}{n} \sum_{i=1}^{n} \frac{1}{y_{i}^{2}}\right)
$$

where $y_{i}$ is the experimental response (dye removal percentage), $\mathrm{n}$ is the number of repetitions under the same experimental conditions (Yen and Li, 2015).

In this study, Taguchi method was used to study the effect of various control factors on the efficient dye removal of $\mathrm{CV}$ from aqueous solution and to determine the significant factors and the optimum levels of experimental factors. The controllable factors (operational parameters) and their levels considered in this study were listed in Table 1. The operational parameters of the adsorption were $\mathrm{pH}$, initial dye concentration, contact time and adsorbent dose. The standardized orthogonal array L9 $\left(3^{4}\right)$ was chosen with four control factors at three levels each. The nine experiments with the details of combinations for each control factor were shown in Table 2.

Table 1: Parameters and their levels in experimental design.

\begin{tabular}{ccccc}
\hline Parameter & Symbol & Level & Level & Level \\
& & 1 & 2 & 3 \\
\hline Initial $\mathrm{pH}$ & $\mathrm{pH}$ & 3 & 6 & 9 \\
$\begin{array}{c}\text { Initial Dye } \\
\text { Concentration } \\
\left(\mathrm{mg} \cdot \mathrm{L}^{-1}\right)\end{array}$ & $\mathrm{C}$ & 2 & 5 & 10 \\
$\begin{array}{c}\text { Contact time } \\
(\mathrm{min})\end{array}$ & $\mathrm{t}$ & 30 & 120 & 360 \\
$\begin{array}{c}\text { Adsorbent } \\
\text { Dose }\left(\mathrm{g} \cdot \mathrm{L}^{-1}\right)\end{array}$ & $\mathrm{A}$ & 0.25 & 1 & 4 \\
\hline
\end{tabular}

ANOVA was used to study the percentage of contribution effect of adsorption parameter like $\mathrm{pH}$, initial dye concentration, contact time and adsorbent dose in the evaluation of dye removal performance of pistachio shell powder. A mathematical model was developed to find the relation between input and output parameters using multiple regression analysis. These models are useful to predict the performance characteristics like dye removal percentage for different combination of process parameters that are within the limits as given in Table 2 without performing experiments. After the experiments listed in Table 2 were 
conducted, a verification experiment was made, which allowed fine tuning of the dye removal process. Within described research, the Minitab statistical software was used for planning the experiments, for statistical analysis of the results, and for computing the optimal parameters of the dye removal process.

Table 2: Orthogonal array for L9 Taguchi's experimental design.

\begin{tabular}{ccccc}
\hline $\begin{array}{c}\text { Expt. } \\
\text { No. }\end{array}$ & $\mathrm{pH}$ & $\mathrm{C}\left(\mathrm{mg} \cdot \mathrm{L}^{-1}\right)$ & $\mathrm{t}(\min )$ & $\mathrm{A}\left(\mathrm{g} \cdot \mathrm{L}^{-1}\right)$ \\
\hline 1 & 3 & 2 & 30 & 0.25 \\
2 & 3 & 5 & 120 & 1.00 \\
3 & 3 & 10 & 360 & 4.00 \\
4 & 6 & 2 & 120 & 4.00 \\
5 & 6 & 5 & 360 & 0.25 \\
6 & 6 & 10 & 30 & 1.00 \\
7 & 9 & 2 & 360 & 1.00 \\
8 & 9 & 5 & 30 & 4.00 \\
9 & 9 & 10 & 120 & 0.25 \\
\hline
\end{tabular}

\section{Resarch Findings}

\subsection{Optimization using Taguchi method}

In this study, the four selected factors, including the $\mathrm{pH}$, initial dye concentration, contact time and adsorbent dose were used (three levels for each factor, See Table 1). While the complete factorial experimental design needs $3^{4}=81$ different experiments to evaluate the influencing factors, according to the Taguchi method, only 9 different experiments were carried out using L9 orthogonal array. The experimental results of the percentage dye removal and the calculated values of $(\mathrm{S} / \mathrm{N})$ ratio for the 9 sets of experiments were shown in Table 3. The average removal shown in Table 3 was the average of three repeated experiments which were respectively denoted by $\mathrm{R} 1, \mathrm{R} 2$, and $\mathrm{R} 3$. The $\mathrm{S} / \mathrm{N}$ ratios were calculated by Eq. (2). According to these results, average percentage removal of dye varied from $45.6 \%$ to $88.1 \%$, and $(\mathrm{S} / \mathrm{N})$ ratio from 35.54 to $39.03 \mathrm{db}$, depending on the combination of the design parameters.

Table 3: Orthogonal array for L9 Taguchi's experimental design and the experimental results of the dye removal.

\begin{tabular}{|c|c|c|c|c|c|c|c|c|c|c|}
\hline \multirow{2}{*}{$\begin{array}{l}\text { Expt. } \\
\text { No. }\end{array}$} & \multicolumn{4}{|c|}{ Factor } & Dye & \multicolumn{2}{|c|}{ Removal \% } & \multirow{2}{*}{$\begin{array}{c}\text { Average Dye } \\
\text { Removal \% }\end{array}$} & \multirow{2}{*}{ std. } & \multirow{2}{*}{ S/N Ratio } \\
\hline & $\mathrm{pH}$ & $\mathrm{C}\left(\mathrm{mg} \cdot \mathrm{L}^{-1}\right)$ & $\mathrm{t}(\min )$ & $A\left(g \cdot L^{-1}\right)$ & $\mathrm{R} 1$ & $\mathrm{R} 2$ & R3 & & & \\
\hline 1 & 3 & 2 & 30 & 0.25 & 49.0 & 43.0 & 44.7 & 45.6 & 3.1 & 37.17 \\
\hline 2 & 3 & 5 & 120 & 1.00 & 60.2 & 59.6 & 59.8 & 59.9 & 0.3 & 35.54 \\
\hline 3 & 3 & 10 & 360 & 4.00 & 89.2 & 89.7 & 89.6 & 89.5 & 0.3 & 39.03 \\
\hline 4 & 6 & 2 & 120 & 4.00 & 75.5 & 72.2 & 75.1 & 74.3 & 1.8 & 37.42 \\
\hline 5 & 6 & 5 & 360 & 0.25 & 80.1 & 77.8 & 79.1 & 79.0 & 1.1 & 37.95 \\
\hline 6 & 6 & 10 & 30 & 1.00 & 88.5 & 88.3 & 87.5 & 88.1 & 0.5 & 38.90 \\
\hline 7 & 9 & 2 & 360 & 1.00 & 67.9 & 65.9 & 68.9 & 67.6 & 1.5 & 36.60 \\
\hline 8 & 9 & 5 & 30 & 4.00 & 78.3 & 81.5 & 79.3 & 79.7 & 1.6 & 38.03 \\
\hline 9 & 9 & 10 & 120 & 0.25 & 63.3 & 58.7 & 62.8 & 61.6 & 2.5 & 35.79 \\
\hline
\end{tabular}


C: Initial Dye Concentration; t: Contact time; A: Adsorbent Dose; std.: standard deviation

The mean $\mathrm{S} / \mathrm{N}$ ratio for each of the three levels of the parameters was summarized as $\mathrm{S} / \mathrm{N}$ response in Table 4, where a level corresponded to a defined value given for each of the four factors: $\mathrm{pH}$, initial dye concentration, contact time and adsorbent dose. It helps to analyze the effect of the control factors based on the delta statistics. Delta values are defined as the difference between the maximum and minimum $\mathrm{S} / \mathrm{N}$ value of each control factor. Assigned ranks are based on delta values; a higher delta value represents rank 1 , the second highest represents rank 2 , etc. This analysis helps to obtain more data about the process under investigation and the highest delta value represents the most influential factor on the dye removal percentage. The results indicate that the adsorbent dose has the strongest effect on the $\mathrm{CV}$ dye removal process with a delta value of 2.52. Initial dye concentration is the second most important factor with a delta value of 2.18 , followed by $\mathrm{pH}$ and the contact time with delta values of 2.17 and 1.61 , respectively.
Table 4: Response table of $\mathrm{S} / \mathrm{N}$ ratio for $\mathrm{CV}$ dye removal percentages of PSP.

\begin{tabular}{ccccc}
\hline Level & $\mathrm{pH}$ & $\mathrm{C}$ & $\mathrm{t}$ & $\mathrm{A}$ \\
\hline 1 & 35.92 & 35.73 & 36.70 & 35.64 \\
2 & 38.09 & 37.18 & 36.25 & 37.01 \\
3 & 36.81 & 37.91 & 37.86 & 38.16 \\
Delta & 2.17 & 2.18 & 1.61 & 2.52 \\
Rank & 3 & 2 & 4 & 1 \\
\hline
\end{tabular}

Using the responses shown in Table 4, graphs of the main effects for dye removal percentage were generated and were shown in Figure 3. As demonstrated in Eq. (2), the greater the $\mathrm{S} / \mathrm{N}$ ratio, the smaller in the variance of dye removal percentage at the desired (the larger-the better) value. The mean $\mathrm{S} / \mathrm{N}$ ratio values were analyzed, and from the highest $\mathrm{S} / \mathrm{N}$ ratio values (Figure 3 ), the optimum level of each factor was determined. The results revealed that the optimal conditions for the removal of dye are $\mathrm{pH}$ at level 2 (pH 6), initial dye concentration at level $3\left(10 \mathrm{mg} \cdot \mathrm{L}^{-1}\right)$, contact time at level 3 (360 mins) and adsorbent dose at level 3 (4 $\left.\mathrm{g} \cdot \mathrm{L}^{-1}\right)$. 


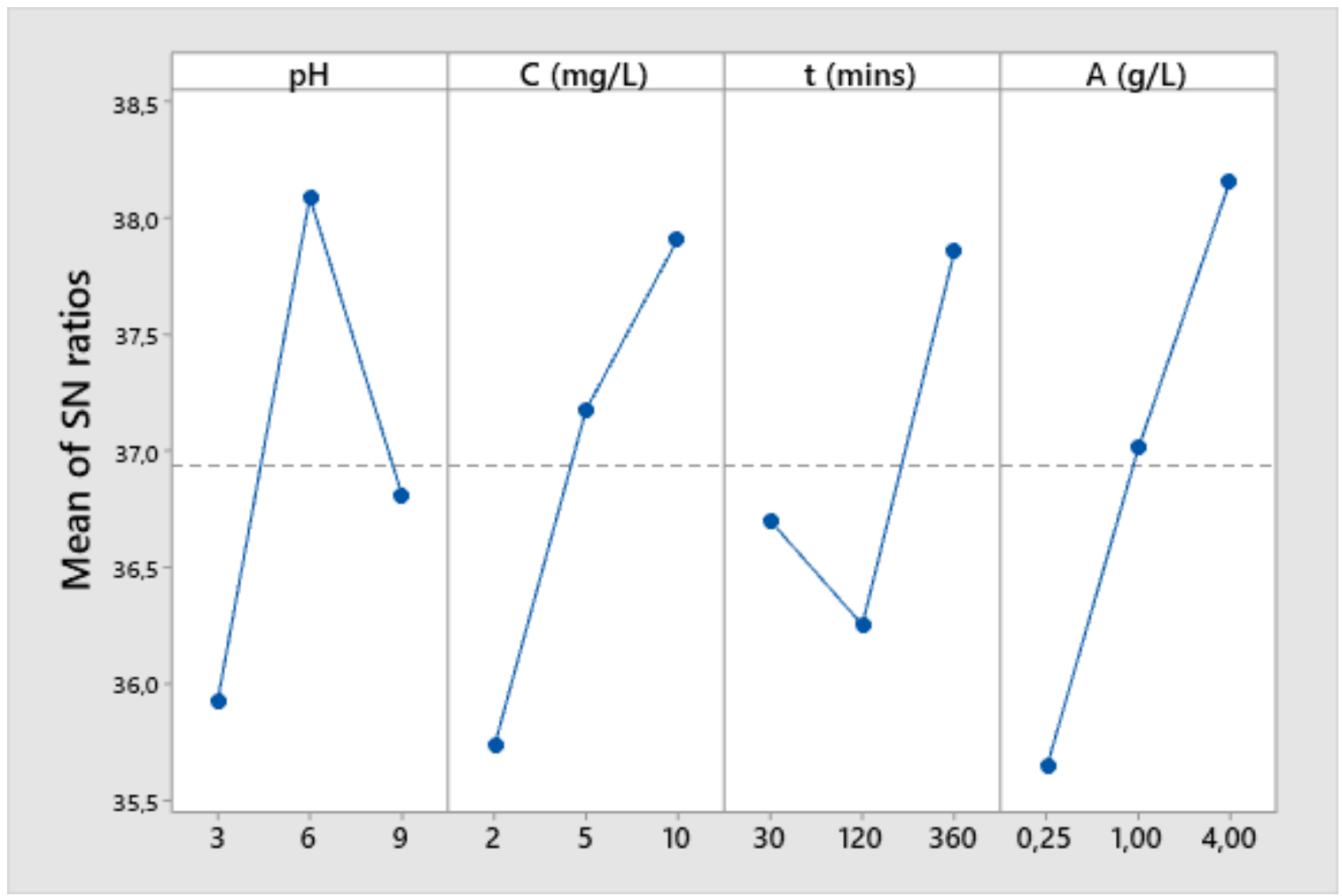

Figure 3: Main effect plots for $\mathrm{S} / \mathrm{N}$ ratios.

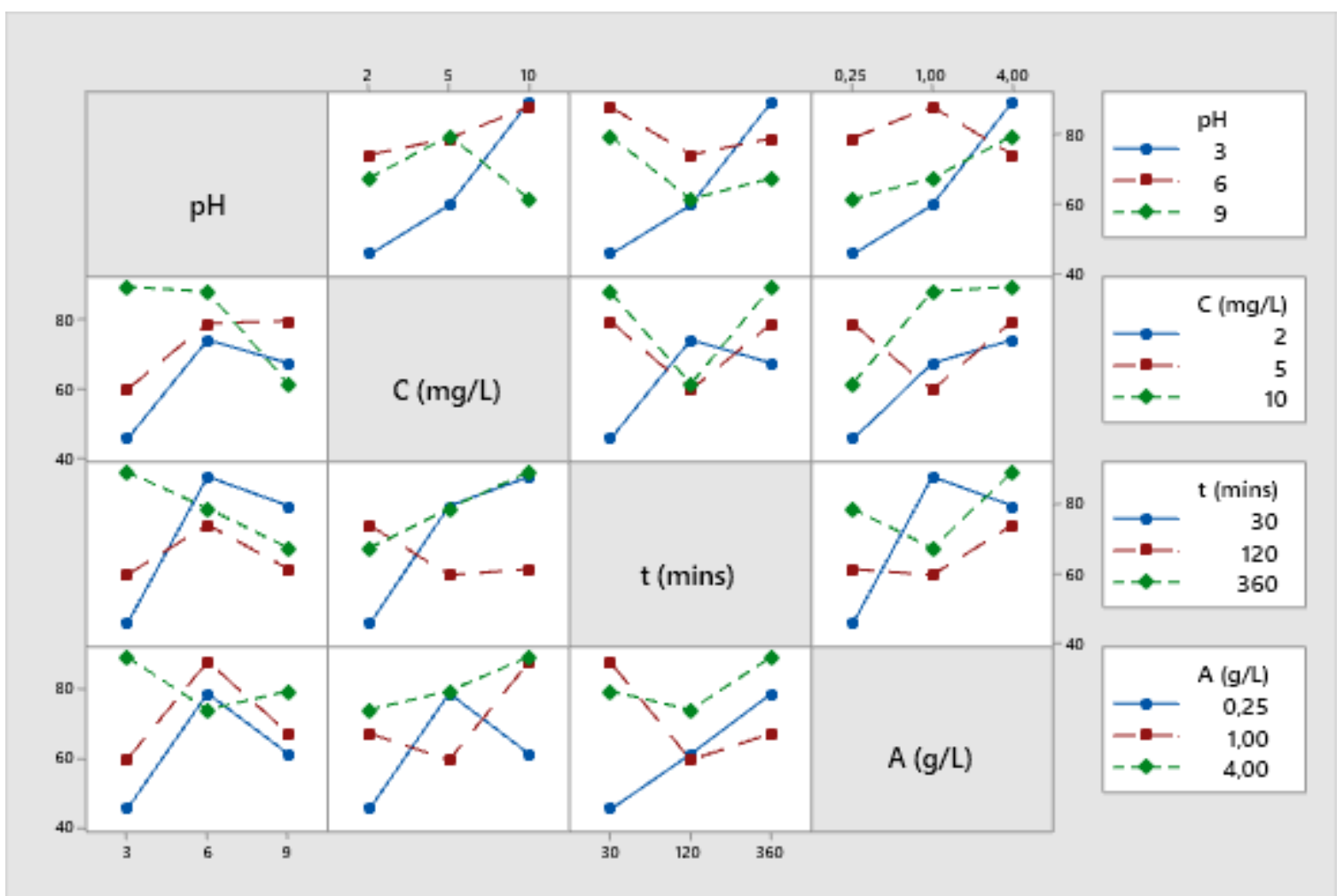

Figure 4: Interaction plots for the means

For the average dye removal percentage interdependence or interaction between the values, Figure 4 illustrated the chosen input parameters. By measuring the 
non-parallel and parallel lines in the plot, the interaction effects of the input parameters can be determined. If the lines are nonparallel, a strong interaction exists between the parameters. On the other hand, a weak interaction exists if the lines are parallel.

\subsection{Analysis of variance of percent dye removal}

ANOVA helps to study the contribution of each factor for attaining the optimum process outcome. In ANOVA table, degree of freedom (DF) is defined as the degree of freedom which provides the detailed information of the factors for analysis. The overall number of experimental runs was used to calculate the total DF. The amount of variation in the response data explained by each term in the model is quantified by adjusted sum of squares (Adj. SS). Adjusted mean of squares (Adj. MS) tests the amount of variation of a factor, irrespective of the order they have entered (Mubina 2019). ANOVA results that detect any differences in the average output of the transformed data were shown in Table 5. Result analysis done using signal-to-noise $(\mathrm{S} / \mathrm{N})$ response analysis and ANOVA analysis shows similar results. The most influential factor was the adsorbent dose because the variance for this factor was the highest. Overall, the percentage contributions are in the following order: adsorbent dose (33.17\%), initial dye concentration (27.43\%), $\mathrm{pH}(22.79 \%)$, and contact time (16.52\%). In view of the fact that the degree of freedom for the error term was 0 (calculated as the difference between the total degree of freedom and the accumulative degree of freedom of all factors), it was not possible to obtain the variance of error $\left(\sigma_{\mathrm{e}}\right)$. Consequently, it was not possible to compute the F-ratio, defined as the variance of each factor $\left(\sigma_{\mathfrak{i}}\right)$ divided by $\sigma_{\mathrm{e}} \quad$ (Elizalde-González and HernándezMontoya, 2009).

Table 5: Analysis of variance for dye removal percentage.

\begin{tabular}{cccccc}
\hline Source & DF & Seq.SS & Adj.SS & Adj.MS & $\begin{array}{c}\% \\
\text { Cont. }\end{array}$ \\
\hline $\mathrm{pH}$ & 2 & 378.0 & 378.0 & 189.0 & 22.89 \\
$\mathrm{C}$ & 2 & 452.9 & 452.9 & 226.5 & 27.43 \\
$\mathrm{t}$ & 2 & 272.7 & 272.7 & 136.4 & 16.52 \\
$\mathrm{~A}$ & 2 & 547.7 & 547.7 & 273.8 & 33.17 \\
Error & 0 & - & - & - & - \\
Total & 8 & 1651.3 & - & - & 100.0
\end{tabular}

DF: degree of freedom. Seq.SS: sequential sum of squares. Adj.SS: adjusted sum of squares. Adj.MS: adjusted mean of squares. \% Cont: percentage contribution.

\subsection{Confirmation Test}

The purpose of the confirmation test is to verify the conclusions that have been drawn after the study. Once the optimum process parameter levels have been determined, the final step is to check that the performance characteristics are enhanced using the optimum level of the processing parameters. Because optimal dye removal conditions determined $(\mathrm{pH} 6$, initial dye concentration $=$ $10 \mathrm{mg} \cdot \mathrm{L}^{-1}$, contact time $=120 \mathrm{mins}$ and adsorbent dose $=4.00 \mathrm{~g} \cdot \mathrm{L}^{-1}$ ) were not present in the experimental process, a verification experiment with optimized dye removal process parameters was performed in order to examine the results of the study. The result of dye removal percentage of the verification test was $93.6 \pm 0.1 \%$. This value is higher than the dye removal percentage of the experiment number $6(\mathrm{pH}=3$, initial dye concentration $=10 \mathrm{mg} \cdot \mathrm{L}^{-1}$, contact time $=$ 360 mins and adsorbent dose $=4.00 \mathrm{~g} \cdot \mathrm{L}^{-1}$ ) that has the highest value $89.5 \% \pm 0.3$ shown in Table 3. It proves that the study's outcome is of importance. 
Furthermore, a multiple linear regression equation was developed to correlate dye removal percentage with the controllable factors under each test. The mathematical model for crystal violet dye removal through the statistical analysis is given as follows:

dye removal $\%=42.3+0.77 p H+$ $2.08 C+0.0298 t+4.53 A$

where $\mathrm{C}$, $\mathrm{t}$, and $\mathrm{A}$ are initial dye concentration, contact time and adsorbent dose, respectively.

\section{Conclusions}

This study reported that pistachio shell powder has the ability to remove crystal violet, a harmful cationic dye, from waste water as an economical adsorbent. In order to find the optimal condition with minimal labor work, Taguchi experiment design was applied as well as to analyze the system's sensitivity to various factors. The average dye removal percentage of the nine experimental results varies from $45.6 \%$ to $89.5 \%$, depending on the combination of the controllable factors. A pH of 6 , initial dye concentration of $10 \mathrm{mg} \cdot \mathrm{L}^{-1}$, contact time of 360 mins and adsorbent dose $=4.00 \mathrm{~g} \cdot \mathrm{L}^{-1}$ were found to be the best conditions for dye removal based on the main effect plot of $\mathrm{S} / \mathrm{N}$ ratio. Adsorbent dose was the most important factor influencing dye removal from ANOVA results and the rank obtained in the response table. From the interaction effect plot, a better understanding of the interactions between different factors at different levels was obtained. Removal of crystal violet on pistachio shell powder is influenced by the factors in the following order: adsorbent dose > initial dye concentration $>\mathrm{pH}>$ contact time.

\section{Acknowledgment:}

The author would like to thank Assoc. Prof.Dr. Halil İbrahim Kurt for his useful discussion in the experiments of the study.

\section{References}

Abd- Elhamid, A. I., Emran, M., El- Sadek, M. H., El- Shanshory, A. A., Soliman, H. M. A., Akl, M. A. and Rashad, M. 2020. "Enhanced removal of cationic dye by eco- friendly activated biochar derived from rice straw", Applied Water Science, 10, 45.

Açıkalın, K., Karaca, F. and Bolat, E. 2012. "Pyrolysis of pistachio shell: Effects of pyrolysis conditions and analysis of products", Fuel, 95, 169-177.

Ardejani, F. D., Badii, K., Limaee, N. Y., Shafaei, S. Z. and Mirhabibi, A. R. 2008. "Adsorption of Direct Red 80 dye from aqueous solution onto almondshells: Effect of $\mathrm{pH}$, initial concentration and shell type", Journal of Hazardous Materials, 151(2-3), 730-737.

Ates, F. and Tezcan Un, U. 2013. "Production of char from hornbeam sawdust and its performance evaluation inthe dye removal", Journal of Analytical and Applied Pyrolysis, 103, 159-166.

Berkane, N., Meziane, S. and Aziri, S. 2020. "Optimization of Congo red removal from aqueous solution using Taguchi experimental design", Separation Science and Technology, 55(2), 278-288.

Chen, Z., Deng, H., Chen, C., Yang, Y. and $\mathrm{Xu}, \mathrm{H}$. 2014. "Biosorption of malachite green from aqueous solutions by Pleurotus ostreatus using Taguchi method", Journal of Environmental Health Science \& Engineering, 12, 63. 
Ding, L., Zou, B., Gao, W., Liu, Q., Wang, Z., Guo, Y., Wang, X. and Liu, Y. 2014. "Adsorption of Rhodamine-B from aqueous solution using treated ricehuskbased activated carbon", Colloids and Surfaces A: Physicochemical and Engineering Aspects, 446, 1-7.

Do, T.-V. and Hsu, Q.-C. 2016. "Optimization of Minimum Quantity Lubricant Conditions and Cutting Parameters in Hard Milling of AISI H13 Steel", Applied Sciences, 6.

El-Geundi, M. S. 1991. "Colour removal from textile effluents by adsorption techniques", Water Research, 25(3), 271273.

Elizalde-González, M. P. and HernándezMontoya, V. 2009. "Removal of acid orange 7 by guava seed carbon: A four parameter optimization study", Journal of Hazardous Materials, 168(1), 515-522.

Ertugay, N. 2018. "The Removal of Crystal Violet (CV) Dyestuff by Wheat Bran: Kinetic Studies", Erzincan University Journal of Science and Technology, 11(3), 435-450.

Fratila, D. and Caizar, C. 2011. "Application of Taguchi method to selection of optimal lubrication and cutting conditions in face milling of AlMg3", Journal of Cleaner Production, 19(6-7), 640-645.

Garg, V. K., Gupta, R., Yadav, A. B. and Kumar, R. 2003. "Dye removal from aqueous solution by adsorption on treated sawdust", Bioresource Technology, 89(2), 121-124.

Gezer, B. and Ersoy, Y. 2018. "Adsorption Behavior of Methylene Blue Dye Using Carob Powder as Eco-Friendly New Adsorbent For Cleaning Wastewater: Optimization By Response Surface Methodology", Erzincan University
Journal of Science and Technology, 11(2), 306-320.

İnal, M. and Erduran, N. 2015. "Removal of various anionic dyes using sodium alginate/ poly(N-vinyl-2-pyrrolidone) blend hydrogel beads", Polymer Bulletin, 72, 1735-1752.

Khan, M. A., Al Othman, Z. A., Kumar, M., Ola, M. S. and Siddique, M. R. 2015. "Biosorption potential assessment of modified pistachio shell waste for methylene blue: thermodynamics and kinetics study", Desalination and Water Treatment, 56(1), 146-160.

Kwak, J.-S. 2005. "Application of Taguchi and response surface methodologies for geometric error in surface grinding process", International Journal of Machine Tools \& Manufacture, 45(3), 327-334.

Madrakian, T., Afkhami, A. and Ahmadi, M. 2012. "Adsorption and kinetic studies of seven different organic dyes onto magnetite nanoparticles loaded tea waste and removal of them from wastewater samples", Spectrochimica Acta Part A: Molecular and Biomolecular Spectroscopy, 99, 102-109.

Maleki, A., Daraei, H., Khodaei, F., Aghdam, K. B. and Faez, E. 2015. "Direct blue 71 dye removal probing by potato peel-based sorbent: applications of artificial intelligent systems", Desalination and Water Treatment, 57(26), 1228112286.

Malik, P. K. and Saha, S. K. 2003. "Oxidation of direct dyes with hydrogen peroxide using ferrous ion as catalyst", Separation and Purification Technology, 31(3), 241-250.

Moussavi, G. and Khosravi, R. 2011. "The removal of cationic dyes from aqueous solutions by adsorption onto pistachio hull 
waste", Chemical Engineering Research and Design, 89(10), 2182-2189.

Pander, A., Hatta, A. and Furuta, H. 2016. "Optimization of catalyst formation conditions for synthesis of carbonnanotubes using Taguchi method", Applied Surface Science, 371, 425-435.

Panizza, M., Barbucci, A., Ricotti, R. and Cerisola, G. 2007. "Electrochemical degradation of methylene blue", Separation and Purification Technology, 54(3), 382387.

Pourebrahim, F., Ghaedi, M., Dashtian, K., Heidari, F. and Kheirandish, S. 2017. "Simultaneous removing of $\mathrm{Pb} 2+$ ions and alizarin red $\mathrm{S}$ dye after their complexation by ultrasonic waves coupled adsorption process: Spectrophotometry detection and optimization study", Ultrasonics Sonochemistry, 35, 51-60.

Punzi, M., Anbalagan, A., Börner, R. A., Svensson, B.-M., Jonstrup, M. and Mattiasson, B. 2015. "Degradation of a textile azo dye using biological treatment followed by photo-Fenton oxidation Evaluation of toxicity and microbial community structure", Chemical Engineering Journal, 270, 290-299.

Robinson, T., Chandran, B. and Nigam, P. 2002. "Effect of pretreatments of three waste residues, wheat straw, corncobs and barley husks on dye adsorption", Bioresource Technology, 85(2), 119-124.

Sabna, V., Thampi, S. G. and Chandrakaran, S. 2016. "Adsorption of crystal violet onto functionalised multiwalled carbon nanotubes: Equilibrium and kinetic studies", Ecotoxicology and Environmental Safety, 134(2), 390-397.

Sachdeva, S. and Kumar, A. 2009. "Preparation of nanoporous composite carbon membrane for separation of rhodamine B dye", Journal of Membrane Science, 329(1-2), 2-10.

Sarıkaya, A. G. and Erden, E. 2020. "Direct Blue 2 Textile Dye Biosorption by Agaricus campestris Biomass: Kinetic, Isotherm and Thermodynamic Studies", Erzincan University Journal of Science and Technology, 13(1), 258-273.

Senthilkumaar, S., Kalaamani, P. and Subburaam, C. V. 2006. "Liquid phase adsorption of Crystal violet onto activated carbons derived from male flowers of coconut tree", Journal of Hazardous Materials, 136(3), 800-808.

Şentürk, İ. and Alzein, M. 2020. "Adsorptive removal of basic blue 41 using pistachio shell adsorbent - Performance in batch and column system", Sustainable Chemistry and Pharmacy, 16, 100254.

Tanyildizi, M. Ş. 2011. "Modeling of adsorption isotherms and kinetics of reactive dye from aqueous solution by peanut hull", Chemical Engineering Journal, 168(3), 1234-1240.

Venkatesha, T. G., Viswanatha, R., Arthoba Nayaka, Y. and Chethana, B. K. 2012. "Kinetics and thermodynamics of reactive and vat dyes adsorption on $\mathrm{MgO}$ nanoparticles", Chemical Engineering Journal, 198-199, 1-10.

Xing, J., Yang, B., Shen, Y., Wang, Z., Wang, F., Shi, X. and Zhang, Z. 2019. "Selective Removal of Acid Fuchsin from Aqueous Solutions by Rapid Adsorption onto Polypyrrole Crosslinked Cellulose/Gelatin Hydrogels", Journal of Dispersion Science and Technology, 40(11), 1591-1599.

Yen, H. Y. and Li, J. Y. 2015. "Process optimization for $\mathrm{Ni}$ (II) removal from wastewater by calcined oyster shell powders using Taguchi method", Journal 
Removal Of Crystal Violet Dye From Aqueous Solution with Pistachio Shell Powder: Optimization Of Process By Taguchi Method

of Environmental Management, 161, 344349.

Zhou, Y., Lu, J., Zhou, Y. and Liu, Y. 2019. "Recent advances for dyes removal using novel adsorbents: A review", Environmental Pollution, 252, 352-365. 